\title{
Monophyly of Ochrosia sensu lato (Apocynaceae): Evidence from ITS, rps16 intron and morphological characters
}

\author{
Hendrian $^{1}$ and Katsuhiko Kondo ${ }^{1,2}$ \\ ${ }^{1}$ Laboratory of Plant Chromosome and Gene Stock, Graduate School of Science, Hiroshima \\ University, 1-4-3 Kagamiyama, Higashi-Hiroshima City, 739-8526, Japan \\ ${ }^{2}$ Author for correspondence: (kkondo@hiroshima-u.ac.jp) \\ Received November 4, 2007; accepted December 29, 2007
}

\begin{abstract}
A phylogenetic analysis of Ochrosia sensu lato (Ochrosia sensu stricto and Neisosperma) was performed based on 14 macromorphological characters scored from 19 species including two varieties (23 accessions), and three outgroup from genus Rauvolfia, i.e. R. sumatrana, $R$. verticillata and $R$. serpentina. For the same species, this data was analyzed together with molecular dataset from our previous studies. The result of total datasets analysis (of ITS, rps16 intron and macromorphological characters) confirmed the monophyly of Ochrosia sensu lato. Ochrosia sensu stricto appeared to be monophyletic. The clade nested within paraphyletic Neisosperma and together they form a strongly supported monophyletic clade of Ochrosia sensu lato. Most of the morphological characters used in this study were found to be homoplasious. The existence of fibrous-fruited group and cavity-fruited group was not supported, thus subdivision of Ochrosia into sections (or subgenera) based on this character as proposed by several authors cannot be applied.
\end{abstract}

KEYWORDS: Macromorphological data, Molecular data, Monophyly. Ochrosia sensu lato, Phylogeny.

Ochrosia sensu lato (or Ochrosia sensu stricto and Neisosperma) consists about 40 species distributed from the Mascarene and Seychelles in the west throughout southern Asia, Indo-China, Malesia, northern Australia, and Pacific Islands as far east as the Marquesas and Hawaiian Islands (Hendrian 2000).

Ochrosia was firstly described by Jussieu (1789). Soon it was found that the morphology of its fruit is quite diverse. Mueller (1871) used these characters as the basis for recognition of two sections: Ochrosia section Lactaria with a massive, thick endocarp containing two lateral cavities filled with spongy tissue, and Ochrosia section Echinocaryon with an endocarp split into diverging fibers.

Fosberg and Sachet (1977) and Fosberg, Boiteau and Sachet (1977) resurrected the name Neisosperma for the fibrous-fruited species, and restricted the name Ochrosia Juss. only to the portion containing the type (the cavityfruited species). Thus, they treated Neisosperma and Ochrosia as two different genera. Some authors, including Markgraf (1979), Boiteau and Allorge (1981), Forster (1993), and Endress and Bruyns (2000) followed this classification.

Since then, the delimitation of the genus and relationship between these two 'groups' has became a long debate.

In a strict phylogenetic classification, genera and other taxa recognized above the species level should be monophyletic (Hennig 1966, Wiley 1981). A monophyletic group of species includes an ancestor and all of its descendants (Forey et al. 1992, Kitching et al. 1998). The descendants all share one or more unique evolutionary novelties (apomorphies), i.e. character states that have been inherited by all its descendants. The presence of one unique character is sufficient to assume monophyly
(Wiley 1981). However, apomorphies developed in the most recent common ancestor can be altered subsequently in one of the descendant branches into a new apomorphy. This and reversals and parallel development may blur the recognition of monophyletic groups. Hennig (1966) distinguished three types of groups: monophyletic, paraphyletic, and polyphyletic. A paraphyletic group is what remains after one or more parts of a monophyletic group have been removed, whilst polyphyletic group is defined on the basis of convergence, conflicting or homoplastic characters assumed to have been absent in the most recent common ancestor of the group (Kitching et al. 1998).

Most systematists acknowledge that there are different kinds of data, e.g. molecular, morphological, anatomical, etc. Some authors prefer to analyze data separately and then use consensus methods to combine the resulting cladograms. Some other argue that all data should be analyzed in a single matrix. This has been called the total evidence or character congruence approach because the final results purely from interaction among all available characters (Kitching et al. 1998).

The aims of this study are mainly to investigate the changes of morphological characters in the phylogeny of Ochrosia sensu lato, and to confirm conclusions from our previous analysis using ITS and ITS + rps16 sequence data.

\section{Material and Methods}

Taxon sampling For total evidence analysis, the same species included in our previous studies were used (Table 1). Nineteen species (23 accessions), consisting of nine Neisosperma spp. and ten Ochrosia s.str. spp. (including two varieties of Ochrosia mariannensis: var. mariannensis 


\section{HENDRIAN AND KONDO}

Table 1. List of the species studied

\begin{tabular}{|c|c|c|c|}
\hline Species & Vouchers & Locality & DDBJ acc. no. \\
\hline \multicolumn{4}{|l|}{ A. For rps 16 intron region: } \\
\hline O. coccinea & IV.A.26 (Bogor Bot. Garden) & Moluccas, Indonesia & AB364606 \\
\hline O. compta & 721228 (NTBG) & Oahu, Hawaii & AB364608 \\
\hline O. kauaiensis & 030324 (NTBG) & Kauai, Hawaii & AB364609 \\
\hline O. mariannensis var. mariannensis & 75s25 (Waimea Arboretum) & Guam & AB364602 \\
\hline O. mariannensis var. crassicarpa & 76s12 (Waimea Arboretum) & Guam & AB364603 \\
\hline Ochrosia sp. & 95s123 (Waimea Arboretum) & Tonga & AB364610 \\
\hline O. mulsanti & MacKee 22097 (L) & New Caledonia & AB364604 \\
\hline O. silvatica & Sevenet $399(\mathrm{~L})$ & New Caledonia & AB364605 \\
\hline O. vitiensis & Smith 9478 (L) & Fiji & AB364611 \\
\hline O. sandwicensis & Spence 7 (L) & Hawaii & AB364607 \\
\hline O. elliptica & 5557 (PTBG) & Kauai, Hawaii & AB364601 \\
\hline N. oppositifolia 1 & IV.A.176 (Bogor Bot. Garden) & Sumatra, Indonesia & AB364615 \\
\hline N. oppositifolia 2 & 82s318 (Waimea Arboretum) & Saipan & AB364616 \\
\hline N. oppositifolia3 & 970511.001 (NTBG) & Tonga & AB364617 \\
\hline N. nakaiana 1 & 740323.001 (NTBG) & Ogasawara, Japan & AB364613 \\
\hline N. nakaiana2 & 75s2230 (Waimea Arboretum) & Ogasawara, Japan & AB364614 \\
\hline N. glomerata & VIII.G.191(Bogor Bot. Garden) & Moluccas, Indonesia & AB364612 \\
\hline N. miana & Jaffre $3273(\mathrm{P})$ & New Caledonia & AB364621 \\
\hline N. thiollierei & MacKee $26988(\mathrm{P})$ & New Caledonia & AB364622 \\
\hline N. kilneri & Forster PIF 29925 (BRI) & Queensland & AB364620 \\
\hline N.poweri & Forster PIF 26594 (BRI) & Queensland & AB364623 \\
\hline N. citrodora & IV.A.200 (Bogor Bot. Garden) & Papua, Indonesia & AB364619 \\
\hline N. acuminata & Leeuwenberg et al. 14542 (A) & Sulawesi, Indonesia & AB364618 \\
\hline$R$. serpentina & XXIV.A.XXI.10 (Bogor Botanic Garden) & Java, Indonesia & AB364598 \\
\hline R. sumatrana & IV.A.106a (Bogor Botanic Garden) & Sumatra, Indonesia & AB364599 \\
\hline R. verticillata & IV.A.193a (Bogor Botanic Garden) & Malay Peninsula, Malaysia & AB364600 \\
\hline \multicolumn{4}{|l|}{ B. For ITS region } \\
\hline O. coccinea & IV.A.26 (Bogor Bot. Garden) & Moluccas, Indonesia & AB331864 \\
\hline O. compta & 721228 (NTBG) & Oahu, Hawaii & AB331873 \\
\hline O. kauaiensis & 030324 (NTBG) & Kauai, Hawaii & AB331875 \\
\hline O. mariannensis var. mariannensis & 75s25 (Waimea Arboretum) & Guam & AB331871 \\
\hline O. mariannensis var. crassicarpa & 76s12 (Waimea Arboretum) & Guam & AB331872 \\
\hline Ochrosia sp. & 95s123 (Waimea Arboretum) & Tonga & AB331870 \\
\hline O. mulsanti & MacKee 22097 (L) & New Caledonia & AB331877 \\
\hline O. silvatica & Sevenet $399(\mathrm{~L})$ & New Caledonia & AB331878 \\
\hline O. vitiensis & Smith $9478(\mathrm{~L})$ & Fiji & AB331869 \\
\hline O. sandwicensis & Spence 7 (L) & Hawaii & AB331874 \\
\hline O. elliptica & 5557 (PTBG) & Kauai, Hawaii & AB331876 \\
\hline N. oppositifolia 1 & IV.A.176 (Bogor Bot. Garden) & Sumatra, Indonesia & AB331858 \\
\hline N. oppositifolia 2 & 82s318 (Waimea Arboretum) & Saipan & AB331859 \\
\hline N. oppositifolia3 & 970511.001 (NTBG) & Tonga & AB331860 \\
\hline N. nakaiana 1 & 740323.001 (NTBG) & Ogasawara, Japan & AB331861 \\
\hline N. nakaiana2 & 75s2230 (Waimea Arboretum) & Ogasawara, Japan & AB331862 \\
\hline N. glomerata & VIII.G.191(Bogor Bot. Garden) & Moluccas, Indonesia & AB331863 \\
\hline N. miana & Jaffre $3273(\mathrm{P})$ & New Caledonia & AB331878 \\
\hline N. thiollierei & MacKee $26988(\mathrm{P})$ & New Caledonia & AB331882 \\
\hline N. kilneri & Forster PIF 29925 (BRI) & Queensland & AB331868 \\
\hline N. poweri & Forster PIF 26594 (BRI) & Queensland & AB331867 \\
\hline N. citrodora & IV.A.200 (Bogor Bot. Garden) & Papua, Indonesia & AB331866 \\
\hline N. acuminata & Leeuwenberg et al. 14542 (A) & Sulawesi, Indonesia & AB331865 \\
\hline$R$. serpentina & XXIV.A.XXI.10 (Bogor Botanic Garden) & Java, Indonesia & AB331857 \\
\hline R. sumatrana & IV.A.106a (Bogor Botanic Garden) & Sumatra, Indonesia & AB365186 \\
\hline R. verticillata & IV.A.193a (Bogor Botanic Garden) & Malay Peninsula, Malaysia & AB365187 \\
\hline
\end{tabular}


and var. crassicarpa) were defined as the ingroup. Three species of Rauvolfia, i.e. $R$. sumatrana, $R$. verticillata and $R$. serpentina were used as the outgroup.

Morphological characters, their character states and the data matrix The morphological analysis was performed using 14 macromorphological characters. The list of characters and their character states are presented in Table 2. Their data matrix can also be seen in Table 3 . These characters and their character states were numbered starting from zero. The data matrix should be based on discrete characters. However, several quantitative characters (i.e. leaves ratio and mericarps length) have been included as well. The character states were treated as unordered, i.e. no a priori designation of the sequence.

The number of characters used was quite few mainly due to the incompleteness of the herbarium specimens examined (some are sterile) and their limited in quantity. The fruit of Ochrosia sp. is not available, thus the states for character number 5 to 14 for this species were regarded as missing data.

Analysis The morphological data then was analyzed together with molecular dataset obtained from our previous studies. Maximum Parsimony analysis was performed using PAUP* ver. $4.0 \mathrm{~b} 10$ (Swofford 2002). Informative characters were unordered and equally weighted. Uninformative characters were excluded. A heuristic search was used to obtain most parsimonious trees (MPT). Starting trees were obtained by stepwise addition, with 1000 random addition sequence replicates. Branch support was evaluated through 1000 replicates of bootstrap analysis (Felsenstein 1985, Kitching et al. 1998, Soltis and Soltis 2003).

\section{Result And Discussion}

The tree Of the 1570 characters (molecular and morphological characters) used in this study, 1334 were constant characters and only $176(11.21 \%)$ were found as parsimony-informative. Four most parsimonious trees of length 429 were yielded. Ensemble consistency and retention indices were 0.73 and 0.84 respectively. Twentyone resolved nodes were found on the strict consensus tree, but only 16 were supported with bootstrap value $>$ $50 \%$ (Fig. 1). It was not significantly different to that found on the strict consensus tree produced from our previous study using ITS + rps16 sequence data, which had 17 resolved and 16 supported nodes. Topologically, the present strict consensus tree was also quite similar to that of ITS + rps16 tree (Hendrian and Kondo, in preparation). All Ochrosia and Neisosperma species were grouped together to form a monophyletic clade of Ochrosia sensu lato strongly supported with $100 \%$ bootstrap value. The monophyletic clade of Ochrosia nested within paraphyletic Neisosperma, confirming the recognition of only one genus as hypothesized before.
Table 2. Characters and their states used in the phylogenetic analysis

1. Habitus:

$0=$ shrub

$1=$ shrub or treelet

$2=$ tree

2. Leaves texture:

$0=$ papyraceous when dried

$1=$ coriaceous or thickly so when dried

3. Leaves ratio:

$0=$ usually elliptic

$1=$ usually narrowly elliptic

4. Corolla-lobes aestivation:

$0=$ sinistrorse

$1=$ dextrorse

5. Ovary:

$$
\begin{aligned}
& 0=\text { syncarpous } \\
& 1=\text { apocarpous }
\end{aligned}
$$

6. Fruit colour when matured:

$$
\begin{aligned}
& 0=\text { black } \\
& 1=\text { whitish purple } \\
& 2=\text { yellow to brownish yellow } \\
& 3=\text { bright red or purplish red }
\end{aligned}
$$

7. Mericarps length:

$$
\begin{aligned}
& 0=\text { less than } 2.5 \mathrm{~cm} \\
& 1=\text { more than } 3.0 \mathrm{~cm} \text { in length }
\end{aligned}
$$

8. Mericarps shape:

$0=$ globose

1 = ovoid, obovoid, or ellipsoid

$2=$ discoid or boat-shape

9. Mericarps in transverse section:

$$
\begin{aligned}
& 0=\text { round } \\
& 1=\text { compressed }
\end{aligned}
$$

10. Lateral ridge at the mericarps:

$$
\begin{aligned}
& 0=\text { absent } \\
& 1=\text { present }
\end{aligned}
$$

11. Shallow longitudinal groove at the mericarps:

$$
\begin{aligned}
& 0=\text { absent } \\
& 1=\text { present }
\end{aligned}
$$

12. Acumen of the mericarps when dried:

$$
\begin{aligned}
& 0=\text { not distinct } \\
& 1=\text { distinct }
\end{aligned}
$$

13. Endocarps:

$$
\begin{aligned}
& 0=\text { massive and stony } \\
& 1=\text { with fine fibers } \\
& 2=\text { with hard fibers }
\end{aligned}
$$

14. Lateral cavities of the endocarp:

$$
\begin{aligned}
& 0=\text { absent } \\
& 1=\text { two and clear } \\
& 2=\text { many, small, and obscure }
\end{aligned}
$$




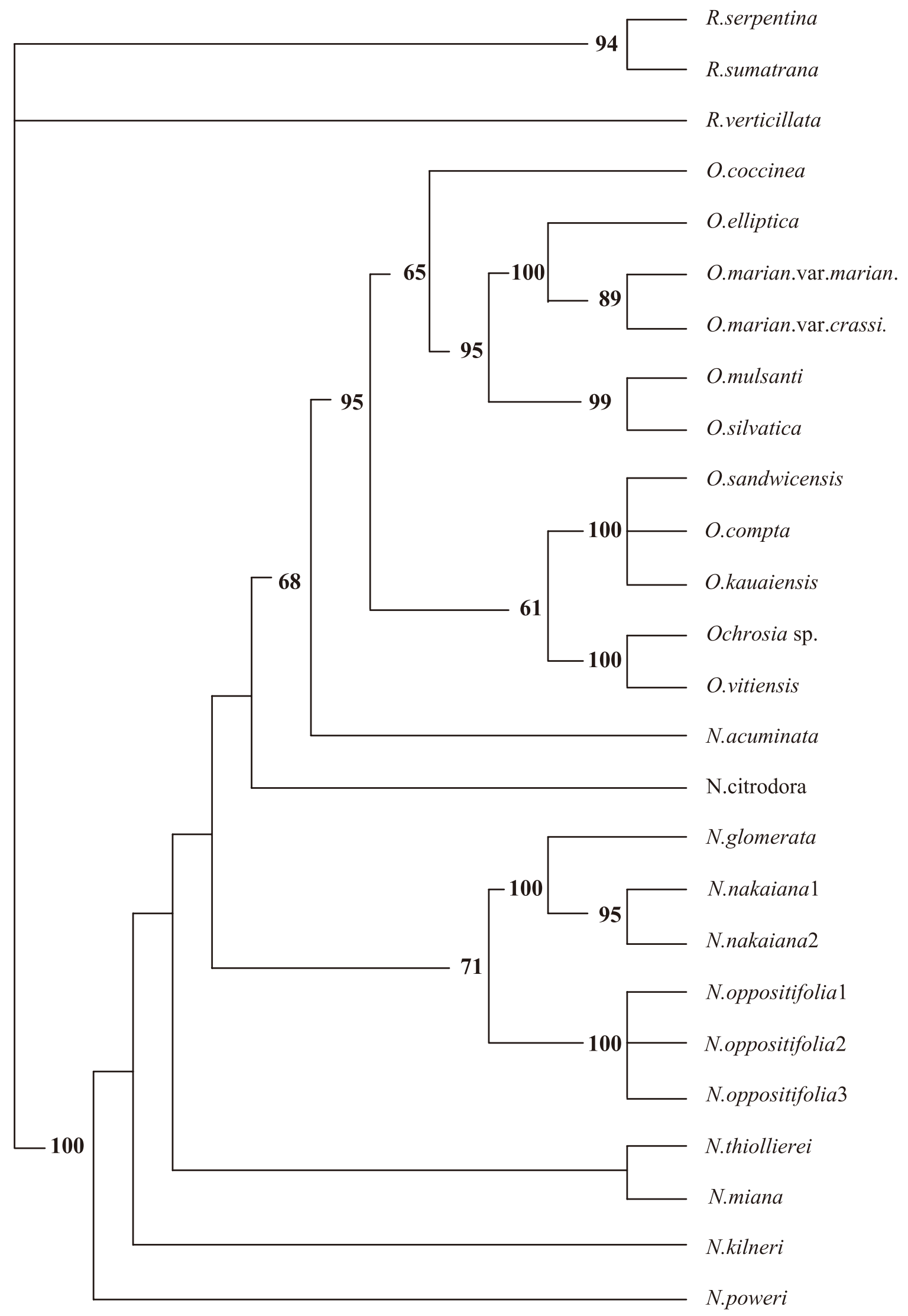

Fig.1. A strict consensus tree of 4 most parsimonious trees (length 429; CI 0.73; RI 0.84) resulting from rps16, ITS, and selected morphological characters dataset. Numbers at the nodes are bootstrap value. 
Table 3. Data matrix of character states used in the phylogenetic analysis

\begin{tabular}{|c|c|c|c|c|c|c|c|c|c|c|c|c|c|c|}
\hline & 1 & 2 & 3 & 4 & 5 & 6 & 7 & 8 & 9 & 10 & 11 & 12 & 13 & 14 \\
\hline R. serpentina & 0 & 0 & 0 & 0 & 0 & 0 & 0 & 1 & 0 & 0 & 0 & 0 & 0 & 0 \\
\hline R. sumatra & 2 & 1 & 1 & 0 & 0 & 0 & 0 & 0 & 0 & 0 & 0 & 0 & 0 & 0 \\
\hline R. verticillata & 0 & 0 & 0 & 0 & 1 & 1 & 0 & 1 & 0 & 0 & 0 & 0 & 0 & 0 \\
\hline O. coccinea & 1 & 0 & 0 & 1 & 1 & 3 & 1 & 2 & 1 & 1 & 1 & 0 & 0 & 1 \\
\hline O. elliptica & 1 & 1 & 0 & 1 & 1 & 3 & 1 & 2 & 1 & 1 & 1 & 0 & 0 & 1 \\
\hline O. var. mariann. & 1 & 1 & 0 & 1 & 1 & 3 & 1 & 2 & 1 & 1 & 1 & 0 & 0 & 0 \\
\hline O. var. crassic. & 1 & 1 & 1 & 1 & 1 & 2 & 1 & 2 & 1 & 1 & 1 & 0 & 0 & 0 \\
\hline O. mulsanti & 0 & 1 & 1 & 1 & 1 & 3 & 0 & 2 & 1 & 1 & 1 & 0 & 0 & 2 \\
\hline O. silvatica & 2 & 0 & 1 & 1 & 1 & $?$ & 1 & 2 & 1 & 1 & 1 & 0 & 0 & 2 \\
\hline O. sandwicensis & 1 & 1 & 0 & 1 & 1 & 2 & 1 & 1 & 0 & 0 & 0 & 0 & 0 & 2 \\
\hline O. compta & 1 & 1 & 0 & 1 & 1 & 2 & 1 & 1 & 0 & 0 & 0 & 0 & 0 & 2 \\
\hline O. kauaiensis & 2 & 1 & 1 & 1 & 1 & 2 & 1 & 1 & 0 & 0 & 0 & 0 & 0 & 2 \\
\hline Ochrosia sp. & 1 & 1 & 0 & 1 & $?$ & $?$ & $?$ & $?$ & $?$ & $?$ & $?$ & $?$ & $?$ & $?$ \\
\hline O. vitiensis & 2 & 1 & 0 & 1 & 1 & 3 & 1 & 2 & 1 & 1 & 1 & 0 & 0 & 0 \\
\hline N. acuminata & 2 & 1 & 0 & 1 & 1 & 0 & 1 & 1 & 0 & 1 & 0 & 1 & 1 & 0 \\
\hline N. glomerata & 2 & 1 & 0 & 1 & 1 & 2 & 1 & 1 & 0 & 0 & 0 & 1 & 1 & 0 \\
\hline N. nakaiana 1 & 1 & 1 & 0 & 1 & 1 & 2 & 1 & 1 & 0 & 0 & 0 & 0 & 1 & 0 \\
\hline N. nakaiana2 & 1 & 1 & 0 & 1 & 1 & 2 & 1 & 1 & 0 & 0 & 0 & 0 & 1 & 0 \\
\hline N. oppositifolia 1 & 2 & 1 & 0 & 1 & 1 & 2 & 1 & 1 & 0 & 0 & 0 & 0 & 1 & 0 \\
\hline N. oppositifolia 2 & 2 & 1 & 0 & 1 & 1 & 2 & 1 & 1 & 0 & 0 & 0 & 0 & 1 & 0 \\
\hline N. oppositifolia 3 & 2 & 1 & 0 & 1 & 1 & 2 & 1 & 1 & 0 & 0 & 0 & 0 & 1 & 0 \\
\hline N. citrodora & 1 & 1 & 0 & 1 & 1 & 3 & 1 & 1 & 0 & 0 & 0 & 0 & 2 & 0 \\
\hline N. kilneri & 2 & 1 & 0 & 1 & 1 & 3 & 1 & 1 & 0 & 0 & 0 & 0 & 2 & 0 \\
\hline N. poweri & 2 & 1 & 1 & 1 & 1 & 3 & 0 & 1 & 0 & 0 & 0 & 1 & 1 & 0 \\
\hline N. thiollierei & 2 & 1 & 1 & 1 & 1 & $?$ & 1 & 1 & 0 & 0 & 0 & 0 & 1 & 0 \\
\hline N. miana & 2 & 1 & 1 & 1 & 1 & 3 & 1 & 1 & 0 & 0 & 0 & 0 & 1 & 0 \\
\hline
\end{tabular}

To compare the tree of present study to the one resulting from our ITS sequencing data, several minor differences can be mentioned. One of which was the presence of a clade formed by $N$. glomerata, N. nakaiana and $N$. oppositifolia, and the basalmost species was $N$. poweri, from Queensland, Australia. In the ITS tree N. glomerata and $N$. nakaiana were grouped together and placed at the very basal of the tree, while three accessions of $N$. oppositifolia formed a separate clade.

Ochrosia s.str. clade was strongly supported with $95 \%$ bootstrap value. The clade then subdivided into two moderately supported subclades. The subdivision was exactly similar to that of tree produced from either ITS or ITS + rps 16 sequence data (Hendrian and Kondo under preparation). The first subclade comprised $O$. coccinea, O. elliptica, O. mariannensis, plus two New Caledonian species-O. mulsanti and $O$. silvatica - which were grouped together. The second subclade consisted of a group of Hawaiian species (O. sandwicensis, O. compta, and $O$. kauaiensis), and another group formed by $O$. vitiensis (endemic to Fiji), and Ochrosia sp. from Tonga.

Notes on several interesting nodes It was showed that there were five character states holding the species of Ochrosia sensu lato (clade A). However, of those five only one state found as unchanged synapomorphy, i.e. dextrorse corolla lobes. Tree habitus, coriaceous leaves, bright or purplish red fruits, and fine fibrous endocarps were found to be homoplasious.

Neisosperma glomerata, N. nakaiana, and $N$. oppositifolia (clade B) were hold by one homoplasious character state, i.e. yellow to brownish yellow fruit when mature. Indeed, this clade was not so robust (moderately supported with $71 \%$ bootstrap value). Comparing it to those of our previous study, in the tree produced from ITS sequencing data $N$. oppositifolia was excluded from the clade formed by $N$. glomerata and $N$. nakaiana, while in the ITS+rps 16 tree the clade formed by these three species was weakly supported with only $57 \%$ bootstrap value. 
146 HENDRIAN AND KONDO

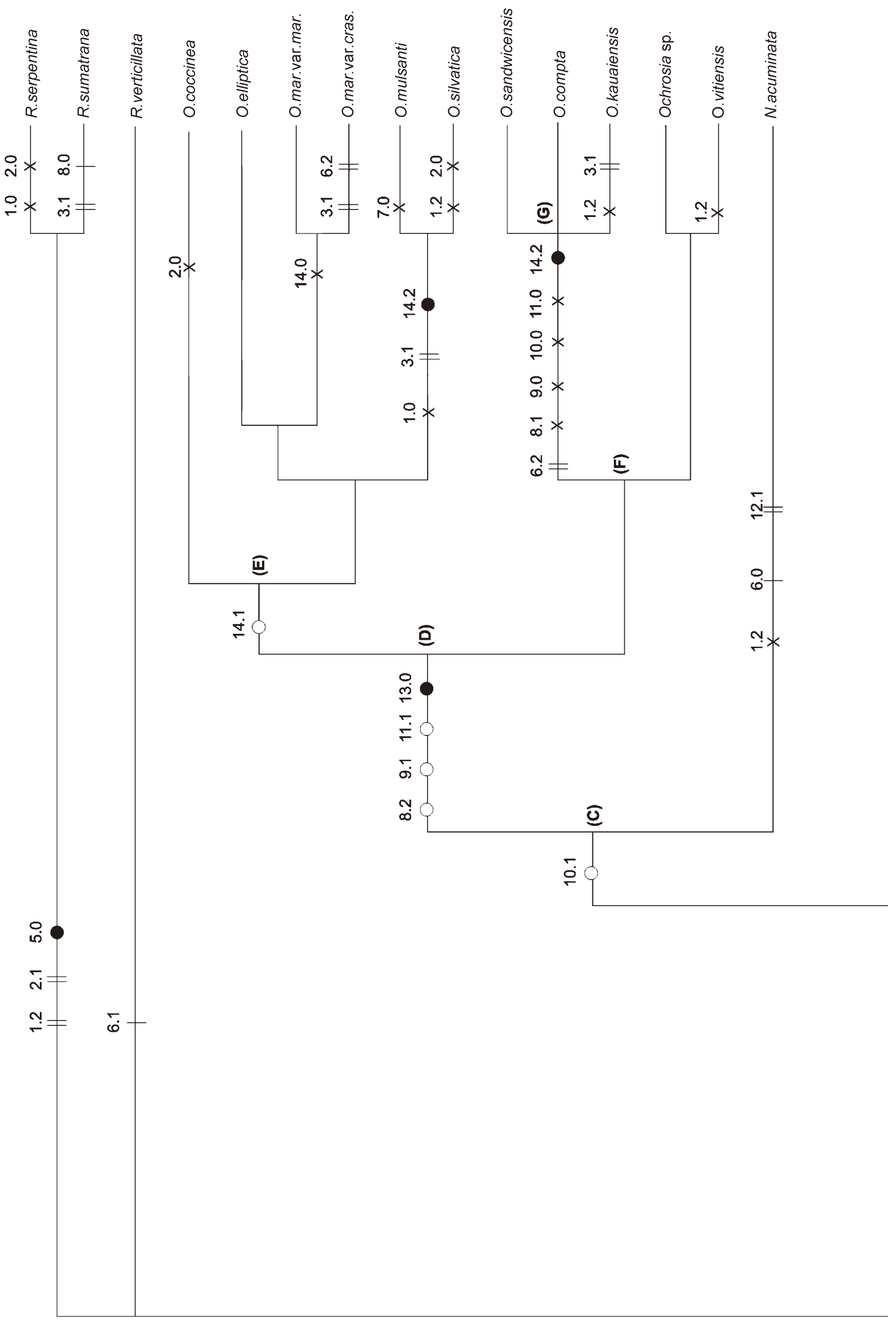


MONOPHYLY OF OCHROSIA SENSU LATO 147
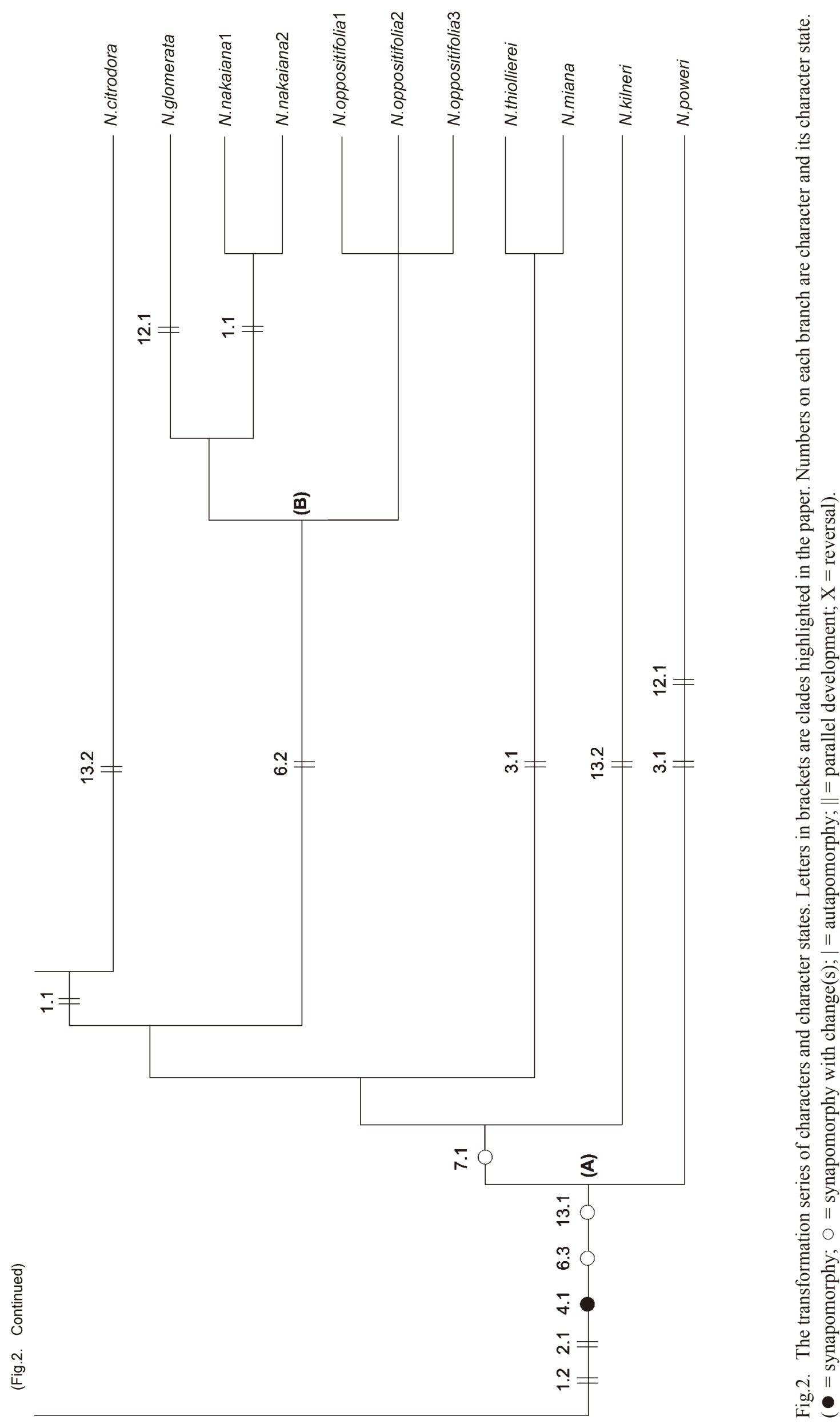
Neisosperma acuminata was found to be the sister species to Ochrosia spp. (clade C). The presence of lateral ridge at the mericarp was found to be the synapomorphy that hold it and all Ochrosia species together. The character state however was homoplasious, showing a reversal event at the node of clade G (Hawaiian Ochrosia).

Massive and stony endocarp was found as the synapomorphy of Ochrosia clade (D). Morphologically, it was one of the characteristics used for discerning two sections of Ochrosia s.l. (Hendrian 2004). No change was found along the branches of the clade, showing that it was owned by all Ochrosia species included in this study.

There were six character states appeared at the node of clade G (Hawaiian Ochrosia) - yellow to brownish yellow fruit, ovoid or ellipsoid mericarp, compressed mericarp, the absence of lateral ridge at the mericarp, the absence of longitudinal groove at the mericarp, and the presence of many, small, obscure lateral cavities in the endocarp - all of which, except the presence of many, small, obscure lateral cavities in the endocarp, were homoplasious.

The changes of the characters In Fig. 2 the transformation of character states was depicted, along with the information of reversal events and parallel development when they occur.

Most of the 14 characters used in this study were found to be homoplasious with reversal events somewhere along the branches and/or parallel development, and thus were less informative. The consistency indices (ci) values for these characters were relatively low. There were only three characters, corolla lobes aestivation, ovary, and mericarps shape, which have ci value more than 0.5 .

The tree produced from the analysis described the changes of the characters. The following is a summary of these changes.

For character no. 1 (habitus), the changes were gradually occurred from tree, to shrub or treelet, and to shrub. But then the character state was reversed from shrub to tree in O. silvatica. In parallel development, three reversal changes from shrub or treelet to tree were also occurred in O. kauaiensis, O. vitiensis, and N. acuminata.

As for character no. 2 (leaves texture), the changes from coriaceous to papyraceous were occurred as parallel development in $O$. coccinea and $O$. silvatica.

The changes from elliptic to narrowly elliptic leaves were found as parallel development in some species $(N$. poweri, N. miana, N. thiollierei, O. mulsanti, O. silvatica, O. mariannensis var. crassicarpa, and O. kauaiensis).

Of all morphological characters used in the present study the presence of dextrorse corolla lobes was the only unchanged synapomorphy for the ingroup species (Ochrosia sensu lato), holding all Ochrosia sensu lato species and separating them from the outgroup. Endress and Bruyns (2000) noted that in Tribe Vinceae dextrorse corolla lobes found in Kopsia, Ochrosia, and Neisosperma.
Syncarpous ovary was only found in two of the outgroup species, Rauvolfia serpentina and $R$. sumatrana. In $R$. serpentina the mericarps are connate at the base for about half of their length, whilst in R. sumatrana the mericarps are almost united entirely. Another outgroup species- $R$. verticillata-has apocarpous ovary, thus the mericarps are clearly separated. Apocarpous ovaries were found in all ingroup species examined.

The colour of mature fruit of Ochrosia and Neisosperma varies from black, yellow, brownish yellow, bright red, to purplish red. Strictly speaking, for the ingroup species examined in this study, bright red or purplish red was found to be plesiomorphic character state. In parallel development it was then changed to yellow and black. Fruit colour for Ochrosia sp., O. silvatica, and $O$. thiollierei is unknown and regarded as missing data.

The mericarp shape of Neisosperma species was ovoid or ellipsoid. This character state was changed to discoid or boat shape at the node of Ochrosia clade (clade D) and then reversed at the node of Hawaiian Ochrosia clade (clade G). Similar to the mericarp shape of Neisosperma species, all Ochrosia species from Hawaiian Islands (St. John 1978, Wagner 1990) are known as having ovoid or ellipsoid mericarps.

As for character 12 (acumen of the mericarps when dried), the changes from not distinct to distinct were found as parallel development in three Neisosperma species ( $N$. poweri, $N$. glomerata, and $N$. acuminata). In $N$. glomerata and $N$. acuminata the acumen often strongly curled and can reach the length of $0.4-1.0 \mathrm{~cm}$.

The endocarps of all Neisosperma species examined excluding $N$. citrodora and $N$. kilneri - split into diverging fine fibrous. The change from fine fibrous to hard fibrous occurred as parallel development in those two Neisosperma species. The change also occurred at node of the Ochrosia clade, from fine fibrous to massive and stony endocarps. All Ochrosia species are known to have massive and stony endocarps. No reversal event was found for this character.

The presence of lateral cavity is found to be homoplasious, changing from two and clear to many and obscure lateral cavities. The character state was also changed to absent in $O$. mariannensis var. mariannensis and $O$. mariannensis var. crassicarpa.

Almost all characters used in this study were found to be homoplasious (with ci values $\leq 0.5$ ). No character state holds all Neisosperma species exclusively. Of the four character states appeared at node of the Ochrosia clade (clade D), only one character state was unchanged, i.e. massive and stony endocarps. Three other characters mericarp shape, mericarp shape in transverse section, and longitudinal groove at the mericarp - were homoplasious (changed somewhere within the clade). On the other hand, the presence of dextrorse corolla lobes was found as a synapomorphy that holds all Ochrosia sensu lato species (clade A). 
ACKNOWLEDGMENTS. The authors have been fully supported by Dissertation PhD Program for 2006 (LIPI 10617), the Japan Society for the Promotion of Science. We wish to thank Drs. Mary Endress, University of Zurich, Switzerland, Tatyana Livshultz, University of Nebraska, Omaha, U.S.A.), David J. Middleton, Royal Botanic Garden, Edinburgh, UK, and Siti Roosita Ariati, Bogor Botanical Garden, Indonesia for discussion and valuable advices, S. Koyano, Subtropical Agriculture Center of Ogasawara, Tokyo, Japan, Erin Fooley, NTBG, Hawaii, U.S.A., David Orr, Waimea Arboretum, Hawaii, U.S.A. and curators of A, BISH, L. \& P. and Koyano, for providing materials, and Goro Kokubugata, Tsukuba Botanical Garden, National Museum of Nature and Dr. Science, Japan) and Joko Ridho Witono, Bogor Botanical Garden, Indonesia for their help.

\section{Literature Cited}

Boiteau, P. and Allorge, L. 1981. Flore de la Nouvelle Caledonie 10. Apocynacees. Museum National D'Histoire Naturelle, Paris.

De Jussieu, A. L. 1789. Genera Plantarum.

De Mueller, F. 1871. Fragmenta Phytographiae Australiae, Vol. VII. Melbourne.

Endress, M. E. and Bruyns, P. V. 2000. A Revised Classification of the Apocynaceae s.l. The Botanical Review 66 (1): $1-56$.

Felsenstein, J. 1985. Confidence limits on phylogenies: an approach using the bootstrap. Evolution 39(4): 783-791.

Forey, P. L., Humphries, C. J., Kitching, I. J., Scotland, R. W., Siebert, D. J. and Williams, D. M. 1992. Cladistics. A Practical Course in Systematics. Clarendon Press, Oxford.

Forster, P. I. 1993. A Taxonomic Revision of Neisosperma Raf. (Apocynaceae) in Australia, Together with A Key to Australian Genera of Apocynaceae. Austrobaileya 4(1):
$13-20$.

Fosberg, F. R. and Sachet, M. H. 1977. Nomenclature of the Ochrosiinae (Apocynaceae): 1. Application of the names Neisosperma Raf. and Calpicarpum G.Don. Adansonia 17(1): 19-22.

Fosberg, F. R., Boiteau, P. and Sachet, M. H. 1977. Nomenclature of the Ochrosiinae (Apocynaceae): 2. Synonymy of Ochrosia Juss. and Neisosperma Raf. Adansonia 17(1): 23-33.

Hendrian. 2004. Revision of Ochrosia (Apocynaceae) in Malesia. Blumea 49(1): 101-128.

Hennig, W. 1966. Phylogenetic Systematics. Univ. of Illinois Press, Urbana, Chicago.

Kitching, I. J., Forey, P. L., Humphries, C. J. and Williams, D. M. 1998. Cladistics. 2nd edition. The theory and practice of parsimony analysis. The Systematic Association Publication no. 11. Oxford University Press, Oxford.

Markgraf, F. 1979. Florae Malesianae Praecursores LIX. Apocynaceae V. Ochrosia, Neisosperma. Blumea 25, 1: 233-247.

Soltis, P. S. and Soltis, D. E. 2003. Applying the bootstrap in phylogeny reconstruction. Statistical Science 18(2): 256-267.

St. John, H. 1978. Ochrosia (Apocynaceae) of the Hawaiian Islands, Hawaiian Plant Studies 60. Adansonia Vol. 18, Ser. 2, No. 2: 199-220.

Swofford, D. L. 2002. PAUP*. Phylogenetic Analysis using Parsimony version 4.0b10. Sinauer Associates, Sunderland, Massachusetts.

Wagner, W. L., Herbst, D. R. and Sohmer, S. H. 1990. Manual of the Flowering Plants of Hawaii, vol. 1, Bishop Museum, Honolulu.

Wiley, E. O. 1981. Phylogenetics: the theory and practice of phylogenetic systematics. Wiley-Interscience, New York. 